\title{
Bazı Siyah Üzüm ve Nar Ürünlerinin Antioksidan Özelliklerinin İncelenmesi
}

\author{
Gamze Toydemir ${ }^{1 *}$ \\ 1'Alanya Alaaddin Keykubat Üniversitesi, Mühendislik Fakültesi, Gıda Mühendisliği Bölümü, Antalya, Türkiye, (ORCID: 0000-0003-3738-0986), \\ gamze.toydemir@alanya.edu.tr
}

(İlk Geliş Tarihi 17 Ocak 2021 ve Kabul Tarihi 25 Nisan 2021)

(DOI: $10.31590 /$ ejosat.918712)

\begin{abstract}
ATIF/REFERENCE: Toydemir, G. (2021). Bazı Siyah Üzüm ve Nar Ürünlerinin Antioksidan Özelliklerinin İncelenmesi. Avrupa Bilim ve Teknoloji Dergisi, (23), 800-809.
\end{abstract}

\section{Öz}

Antioksidan özellikteki biyoaktif bileşenlerce zengin gıdalar arasında yer alan meyvelerin, mevsimsel olarak üretilmeleri ve kısıtlı bir raf ömrüne sahip olmaları nedeniyle, farklı ürünlere işlenerek saklanması sağlanmakta, ve bu nedenle, meyvelerdeki biyoaktif bileşenler çoğunlukla işlenmiş meyve ürünleri içerisinde tüketilmektedir. Son yıllarda tüketicilerin doğal ve fonksiyonel ürün arayışlarının giderek artması sonucu, geleneksel metotlarla işlenmiş meyve ürünleri yeni alternatifler olarak tekrar karşımıza çıkmaktadır. Bu çalışmada, Türkiye'de yaygın olarak yetiştiriciliği yapılan ve antioksidan özellikleri ile ön plana çıkan meyvelerden olan siyah üzüm ve nar meyvelerinin hem dünya genelinde yaygın olan hem de ülkemize özgü tüketim şekilleriyle ön plana çıkan ürünlerinin, tüketildikleri haliyle (yaş madde bazında), sağladıkları antioksidan madde miktarı ve gösterdikleri antioksidan aktivitenin incelenmesi amaçlanmıştır. Bu kapsamda, yerel üreticilerden temin edilen bazı siyah üzüm ürünleri (üzüm suyu, koruk suyu, hardaliye, üzüm sirkesi ve üzüm pekmezi) ve nar ürünlerinin (nar suyu, nar ekşisi, fermente nar ekşisi, nar sirkesi ve nar pekmezi) toplam fenolik madde, toplam flavonoid madde ve toplam monomerik antosiyanin miktarları ile toplam antioksidan kapasite değerleri spektrofotometrik yöntemlerle belirlenmiş ve, aynı meyve grubu bazında, karşılaştırmalı olarak incelenmiştir. Siyah üzüm ürünlerinden üzüm suyu, koruk suyu ve hardaliyenin; nar ürünleri arasından ise nar ekşisi, fermente nar ekşisi ve nar pekmezinin birbirleriyle daha yakın ve daha yüksek antioksidan değerler verdikleri tespit edilmiştir. Ürünler arasında yapılan karşılaştırmalar, geleneksel pekmez üretim metodunun, özellikle üzümde, başta antosiyanin grubu bileşenler olmak üzere, antioksidan madde miktarı ve dolayısıyla, antioksidan kapasitede önemli bir düşüşe neden olduğunu göstermektedir $(\mathrm{p}<0.05)$. Fermente nar ekşisi üretiminde uygulanan fermantasyon basamağının ise, nar ekşisine oranla, toplam fenolik, toplam flavonoid ve toplam monomerik antosiyanin miktarları ile toplam antioksidan kapasitede (DPPH ve ABTS metotları) önemli bir artış (sırasıyla, \%173, \%34, \%78, \%19 ve \%34 artış) olmasına katkıda bulunduğu belirlenmiştir $(\mathrm{p}<0.05)$.

Anahtar Kelimeler: Siyah Üzüm, Nar, Geleneksel Ürün, Antioksidan.

\section{Investigating the Antioxidant Properties of Some Black Grape and Pomegranate Products}

\begin{abstract}
Fruits, which are rich in antioxidant bioactives, are generally processed into a variety of products because of their short shelf-lives as seasonally grown crops. Therefore, fruit bioactives are usually consumed in processed form through these fruit products. In recent years, fruit products obtained through traditional processing methods have attracted attention as new natural and functional food alternatives that correspond to the increasing demand of consumers for these products. In this study, it is aimed to determine the antioxidant contents and activities, in "as is" (wet weight) basis, of some world-wide and traditionally consumed products of antioxidant rich black grape and pomegranate fruits which are widely cultivated in Turkey. Within this context, total phenolic, total flavonoid and total monomeric
\end{abstract}

${ }^{*}$ Sorumlu Yazar: gamze.toydemir@alanya.edu.tr 
anthocyanin contents as well as total antioxidant capacities of some black grape products, including grape juice, verjuice, hardaliye, grape vinegar, and grape molasses, and some pomegranate products, including pomegranate juice, sour pomegranate syrup, fermented sour pomegranate syrup, pomegranate vinegar, and pomegranate molasses, were determined using spectrophotometric methods and evaluated by comparisons within the same fruit group. Within the black grape products, grape juice, verjuice, and hardaliye; and within the pomegranate products, sour pomegranate syrup, fermented sour pomegranate syrup, and pomegranate molasses were measured to exert comparable and higher antioxidant values. The comparisons among the products, those belong to the same fruit group, revealed that the traditional molasses processing led to significant reductions in the contents of antioxidants, primarily anthocyanins, and hence, in antioxidant capacity, specifically in grape molasses $(\mathrm{p}<0.05)$. On the other hand, the fermentation process applied in fermented sour pomegranate syrup processing gave rise to significant increases in total phenolic (173\%), total flavonoid (34\%), and total anthocyanin $(78 \%)$ contents, as well as in total antioxidant capacites, determined by DPPH (19\%) and ABTS (34\%) methods (p<0.05).

Keywords: Black Grape, Pomegranate, Traditional Product, Antioxidant

\section{Giriş}

Meyveler, antioksidan özellikteki biyoaktif bileşenlerce zengin gıdalar olarak, son yıllarda hem tüketicilerin hem de gıda üreticilerinin artan ilgisiyle karşılaşmaktadır (Hidalgo ve Pilar Almajano, 2017). Antioksidanların oksidatif hasarı önleme ve bu hasarın neden olduğu, obezite, kanser, diyabet, kardiyovasküler hastalıklar, vb., birçok kronik hastalıkla mücadele etmedeki etkin rolleri, bu biyoaktif bileşenlerce zengin gıdaların günlük diyetteki önemini vurgulamaktadır (Cory ve ark., 2018). Anavatanı Anadolu sınırları içerisinde yer alan ve Türkiye'de yaygın olarak yetişiriciliği yapılan siyah üzüm (Türkmen Özen, 2015) ve nar (Hoca, 2019) antioksidan özellikleri ile ön plana çıkan meyveler arasında yer almaktadır. Koyu renkli üzüm türleri, kateşin, epikateşin, resveratrol ve fenolik asitler gibi çoğu üzüm çeşidinde ortak olarak bulunan fenolik bileşiklerin yanı sıra antosiyanin grubu fenolikleri de içermekte (Cantos ve ark., 2002) ve bu sayede, doğal antioksidan bileşenlerce zengin bir kaynak olarak yüksek antioksidan aktivite göstermektedir (Liu ve ark., 2018). Nar meyvesi de antosiyaninler, elajik asit türevleri ve hidrolize olabilen tanenler gibi polifenoller bakımından zengin bir ürün olarak yüksek antioksidan potansiyele sahiptir (Gil ve ark., 2000; Kalaycığlu ve Erim, 2016).

Öte yandan, meyveler, mevsimsel olarak üretilmeleri ve kısıtlı bir raf ömrüne sahip olmaları nedeniyle farklı ürünlere işlenerek kalitelerinin korunması sağlanmakta (Rababah ve ark., 2013) ve bu nedenle, meyvelerdeki biyoaktif bileşenler çoğunlukla işlenmiş meyve ürünleri içerisinde tüketilmektedir (Wu ve ark., 2006). Dünya genelinde daha çok meyve suyu, kurutmalık, sofralık ve alkollü içecek sanayinde değerlendirilen üzüm, ülkemizde, bunlara ek olarak, geleneksel tüketim şekilleriyle de yaygın olup, pekmez, pestil, sirke, koruk suyu, koruk ekşisi (Ergezer ve ark., 2018; Otağ, 2015) ve hardaliye (Aydoğdu ve ark., 2014) ürünlerine de işlenmektedir. Bilinen en eski meyve türlerinden biri olan nar ise, ülkemiz genelinde taze meyve olarak tüketildiği gibi, nar suyu, nar konsantresi, nar ekşisi, nar şarabı, nar reçeli, nar şurubu, nar pekmezi, nar sirkesi gibi alternatif tüketim şekilleriyle de karşımıza çıkmaktadır (Özmert Ergin, 2019).

Tüketicilerin doğal ve fonksiyonel ürün arayışlarının giderek artması sonucu, tüketimi sınırlı olan geleneksel ürünler, son zamanlarda, yeni alternatifler olarak tekrar karşımıza çıkmakta ve bu ürünlerin fonksiyonel özelliklerinin belirlenmesine yönelik araştırmalara daha çok gereksinim duyulmaktadır (Öncül ve Karabıyıklı, 2015). Bu bilgiler ışığında, bu çalışmada, siyah üzüm ve nar meyvelerinin hem dünya genelinde yaygın olan hem de ülkemize özgü tüketim şekilleriyle ön plana çıkan ürünlerinin antioksidan özelliklerinin (toplam fenolik madde, toplam flavonoid madde, toplam monomerik antosiyanin ve toplam antioksidan kapasite), aynı meyve grubu bazında, karşılaştırmalı olarak incelenmesi amaçlanmıştır. Bu kapsamda, siyah üzüm ürünleri arasından, üzüm suyu, koruk suyu, hardaliye, üzüm sirkesi ve üzüm pekmezi (Şekil 1); nar ürünleri arasından ise, nar suyu, nar ekşisi, fermente nar ekşisi, nar sirkesi ve nar pekmezi ürünleri (Şekil 2) seçilmiştir. $\mathrm{Bu}$ ürünlerin antioksidan özelliklerinin ayrı ayrı incelendiği literatür çalışmaları mevcut olmakla birlikte; geleneksel ürünler için yapılmış olan çalışma sayısı sınırlı olup (Coşkun ve ark., 2017; Faikoğlu, 2014; Kamiloğlu ve Çapanoğlu, 2014; Orak, 2009; Öncül ve Karabıyıklı, 2015; Özmert Ergin, 2020; Tüzün ve ark., 2020; Vatansever, 2018); bilindiği kadarıyla, seçilen ürünlerin, aynı meyve grubu bazında, tümünün antioksidan özelliklerinin karşılaştırıldığı bir çalışma bulunmamaktadır.

\section{Materyal ve Metot}

\subsection{Materyal}

Siyah üzüm ürünleri (üzüm suyu, koruk suyu, hardaliye, üzüm sirkesi ve üzüm pekmezi) (Şekil 1) ve nar ürünleri (nar suyu, nar ekşisi, fermente nar ekşisi, nar sirkesi ve nar pekmezi) (Şekil 2) yerel üreticilerden 3 tekrarlı olarak temin edilmiştir. Numuneler analize alınıncaya kadar ambalajları üzerinde belirtilen saklama koşullarına uygun olarak muhafaza edilmiştir.

Analizler için kullanılan tüm kimyasallar analitik saflıkta olup Sigma-Aldrich (Steinheim, Almanya) ve Merck (Darmstadt, Almanya) firmalarından temin edilmiştir.

\subsection{Suda Çözünür Kuru Madde Miktarı Tayini}

Numunelerin suda çözünür kuru madde (SÇKM) miktarları ( ${ }^{\circ}$ Briks) $20^{\circ} \mathrm{C}$ 'de refraktometre (Atago PAL-1, Tokyo, Japonya) ile tayin edilmiştir.

\subsection{Ekstraksiyon}

Antioksidan analizleri öncesi tüm numuneler $\% 0.1$ formik asit içeren metanol:su (6:4, hacmen) ile 1:5 (numune:(metanol:su), hacmen) oranında karıştırılmış ve vorteks ile homojenize edilmiştir.

\subsection{Toplam Fenolik Madde Analizi}

Toplam fenolik madde (TFEM) analizi Tezcan ve ark. (2009) tarafından belirtilen metoda uygun olarak gerçekleştirilmiştir. 300 $\mu \mathrm{L}$ seyreltilmiş ekstrakt $1.5 \mathrm{~mL}$ Folin-Ciocalteau reaktifi (1:10, v/v) ve $1.2 \mathrm{~mL} \mathrm{Na} \mathrm{CO}_{3}(\% 7.5)$ ile karıştırılmış ve $90 \mathrm{dk}$ süre ile oda sıcaklığında inkübe edilmiștir. İnkübasyon süresi sonunda spektrofotometre (Shimadzu UV-1800, Japonya) ile 760 nm'de absorbans ölçümü yapılmış ve TFEM miktarı mg gallik asit eşdeğeri (GAE)/100 mL numune olarak ifade edilmiştir. Gallik asit standart eğrisi $0.01-0.08 \mathrm{mg} / \mathrm{mL}$ konsantrasyon aralığında elde edilmiştir $\left(\mathrm{R}^{2}=0.998\right)$. 


\section{Siyah üzüm}
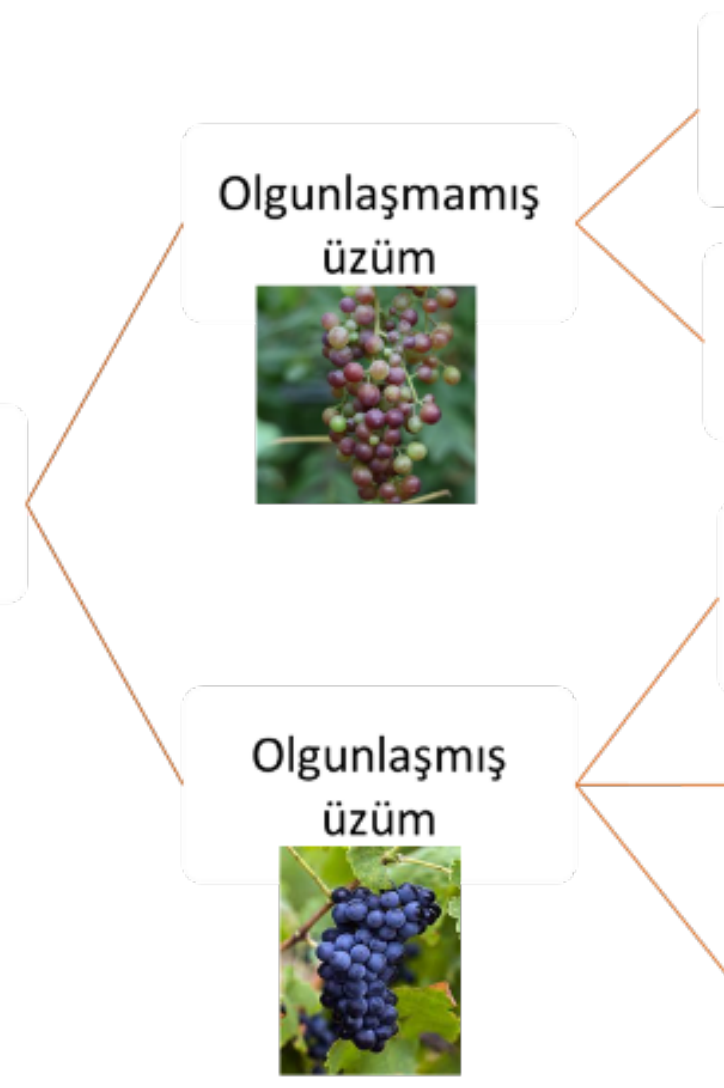

\section{Koruk suyu}

(Olgunlaşmamış üzümlerin ezilip suyunun çıkartılmasıyla elde edilen bir üründür.)

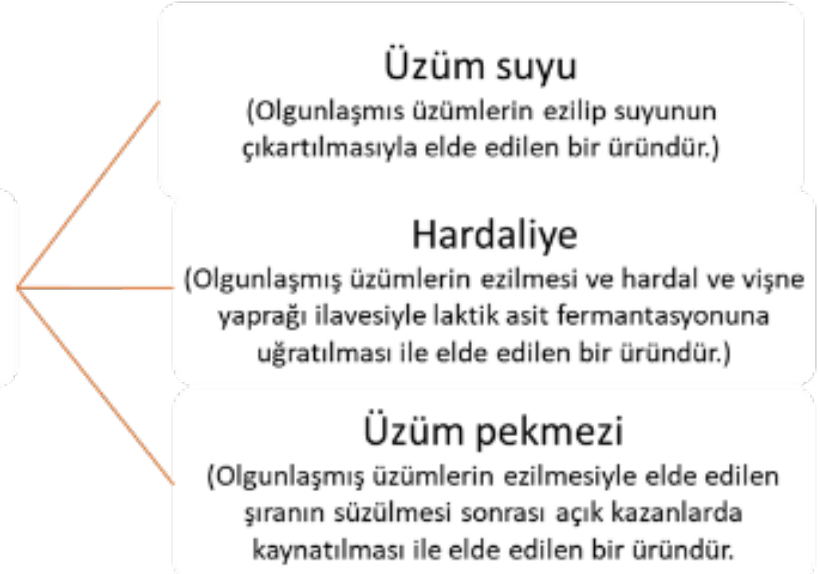

Şekil 1. Siyah üzüm ürünleri ve genel ürün tanımları

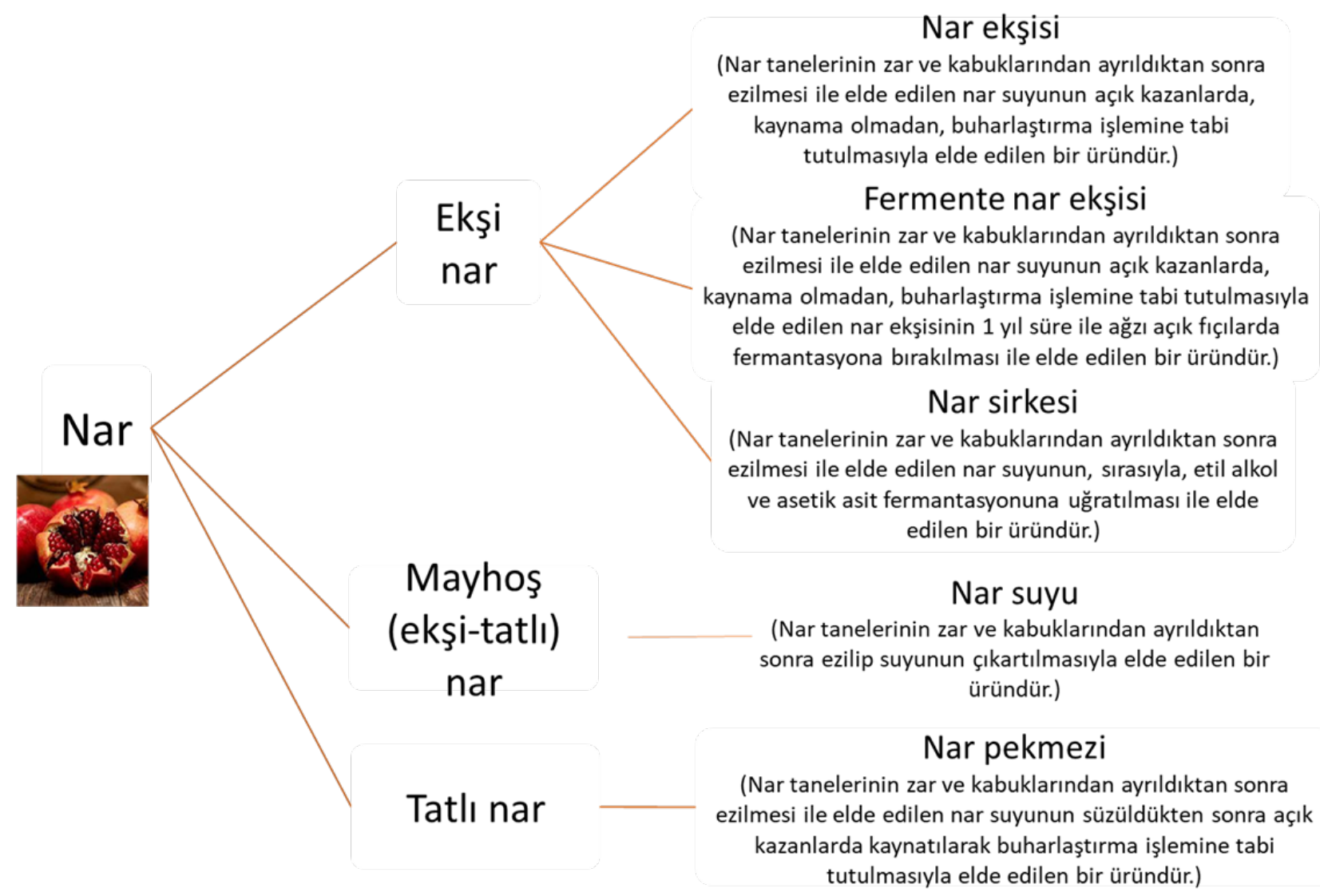

Şekil 2. Nar ürünleri ve genel ürün tanımları 


\subsection{Toplam Flavonoid Madde Analizi}

Toplam flavonoid madde (TFLM) analizi Zhishen ve ark. (1999) tarafindan uygulanan metot takip edilerek gerçekleştirilmiştir. $250 \mu \mathrm{L}$ seyreltilmiş ekstrakta $1.25 \mathrm{~mL}$ saf su ve $75 \mu \mathrm{L} \mathrm{NaNO}_{2}(\% 5)$ ilave edilmiş ve $5 \mathrm{dk}$ oda sıcaklığında inkübe edilmiştir. Daha sonra, $150 \mu \mathrm{L} \mathrm{AlCl} 3.6 \mathrm{H}_{2} \mathrm{O}(\% 10)$ eklenmiş ve $1 \mathrm{dk}$ sonrasında $500 \mu \mathrm{L} 1 \mathrm{M} \mathrm{NaOH}$ ile $275 \mu \mathrm{L}$ saf su ilave edilmiştir. Spektrofotometre ile $510 \mathrm{~nm}$ 'de absorbans ölçümü yapılmış ve TFLM miktarı mg kateşin eşdeğeri (KE)/100 mL numune olarak verilmiştir. (+)-Kateşin standart eğrisi $0.01-0.6 \mathrm{mg} / \mathrm{mL}$ konsantrasyon aralığında elde edilmiştir $\left(\mathrm{R}^{2}=0.998\right)$.

\subsection{Toplam Monomerik Antosiyanin Tayini}

Toplam monomerik antosiyanin (TMA) tayini için $\mathrm{pH}$ diferansiyel metodu (AOAC Official Method 2005.02) uygulanmıştır (Lee ve ark., 2005). Bu metoda göre, $\mathrm{pH} 1.0$ ve $\mathrm{pH} \quad 4.5$ 'e ayarlanmış numunelerin spektrofotometrede antosiyaninlerin maksimum absorbans verdiği dalga boyunda ( $\lambda$ vis-max $\approx 520 \mathrm{~nm}$ ) ölçülen absorbans değerlerinin farkı, direkt olarak numunelerdeki antosiyanin konsantrasyonu ile orantılıdır. Metotta tarif edilen şekilde, numune ekstraktları için en uygun seyreltim oranı $\mathrm{pH} 1.0$ tampon çözeltisi ( $\mathrm{KCl}, 0.025$ M) kullanılarak belirlenmiş ve seyreltim oranı belirlenirken, spektrofotometrede $520 \mathrm{~nm}$ 'de ölçülen absorbans değeri için, birçok spektrofotometrenin linear sınırı olan 1.2 absorbans değeri (Cemeroğlu, 2007) dikkate alınmıştır. Belirlenen seyreltim oranı, numunelere, $\mathrm{pH} 1.0$ tampon çözeltisi ve $\mathrm{pH} 4.5$ tampon çözeltisi $\left(\mathrm{CH}_{3} \mathrm{CO}_{2} \mathrm{Na} .3 \mathrm{H}_{2} \mathrm{O}\right)$ kullanılarak uygulanmış ve her iki tampon çözeltisi ile seyreltilen numunelerin absorbans değerleri, 15 dk'lık bekleme süresi sonunda, spektrofotometre ile $520 \mathrm{~nm}$ ve $700 \mathrm{~nm}$ (bulanıklıktan gelebilecek hatanın düzeltilmesi için)'de ölçülmüştür. Numunelerdeki TMA miktarı aşağıda verilen eşitlik kullanılarak; siyah üzüm ürünleri için mg malvidin-3-glukozit eşdeğeri (M3GE)/L numune, nar ürünleri için ise siyanidin-3glukozit eşdeğeri (C3GE)/L numune olarak hesaplanmıştır. Daha sonra gerekli düzenlemeler yapılarak, sonuçlar, üzüm ürünleri için $\mu \mathrm{g} \mathrm{M} 3 \mathrm{GE} / 100 \mathrm{~mL}$ numune, nar ürünleri için $\mu \mathrm{g}$ C3GE/100 mL numune olarak verilmiştir.

Toplam monomerik antosiyanin $(T M A)(m g / L)=(A x M W x D F x$ $\left.10^{3}\right) /(\varepsilon x L)$

$A=(A 520 \mathrm{~nm}-A 700 \mathrm{~nm}) \mathrm{pH} 1.0-\left(\right.$ A520nm $\left.-A_{700 \mathrm{~nm}}\right) \mathrm{pH} 4.5$; $M W(C 3 G)=C 3 G$ için molekül ă̆ırliğl; $449.2 \mathrm{~g} / \mathrm{mol}$; $M W(M 3 G)=M 3 G$ için molekül ă̆ırlı̆̆ $; 493.2 \mathrm{~g} / \mathrm{mol}$ $D F=$ Seyreltme faktörü;

$\mathcal{E}(C 3 G)=C 3 G$ için molar absorpsiyon katsayısı; 26900 Lxmol $^{-}$ ${ }^{1} \mathrm{xcm}^{-1}$

$\varepsilon(M 3 G)=M 3 G$ için molar absorpsiyon katsayısı; $28000 \mathrm{Lxmol}^{-1} \mathrm{xcm}^{-1}$

$L=$ Absorbans ölçüm küvetinin tabaka kalınlı̆̆ $(\mathrm{cm})$;

$10^{3}=$ g'dan mg'a çevirme faktörü.

\subsection{Toplam Antioksidan Kapasite Analizleri}

Numunelerin toplam antioksidan kapasite (TAK) değerlerinin belirlenmesinde, 2,2-difenil-1-pikrilhidrazil (DPPH), 2,2-azinobis(3-etilbenzotiazolin-6-sülfonik asit diamonyum tuzu) (ABTS) ve bakır (II) iyonu indirgenme antioksidan kapasitesi (CUPRAC) metotları olmak üzere üç farklı metot kullanılmıştır. Gıda ürünlerinin antioksidan kapasitesinin tespitinde tek bir metot prensibine bağlı kalınmasının doğru bir değerlendirme için yeterli olmayacağı, farklı çalışma prensiplerine sahip birden fazla in vitro metodun uygulanmasının daha gerçekçi bir değerlendirme için gerekli olduğu belirtilmiştir (Capanoglu ve ark., 2018). Bu nedenle bu çalışmada, TAK ölçümü için 3 farklı in vitro analiz metodu uygulanmıştır.

DPPH metodu Kumaran ve Karunakaran (2006) tarafindan belirtilen metoda uygun olarak gerçekleştirilmiştir. $100 \mu \mathrm{L}$ seyreltilmiş ekstrakt $2 \mathrm{~mL} 0.1 \mathrm{mM}$ metanolda çözünmüş DPPH reaktifi ile karıştırılmış ve $30 \mathrm{dk}$ süre ile oda sıcaklığında inkübe edilmiştir. İnkübasyon süresi sonunda spektrofotometre ile 517 nm'de absorbans ölçümü yapılmış ve TAK değeri mg Trolox eşdeğeri (TE)/100 mL numune olarak ifade edilmiştir. Trolox standart eğrisi $0.02-0.4 \mathrm{mg} / \mathrm{mL}$ konsantrasyon aralığında elde edilmiştir $\left(\mathrm{R}^{2}=0.997\right)$.

ABTS metodu Miller ve Rice-Evans (1997) tarafindan uygulanan metot takip edilerek gerçekleştirilmiştir. Numuneler ile karıştırılacak ABTS solüsyonunun eldesi için, ABTS stok solüsyonu $0.05 \mathrm{M}$ potasyum fosfat tampon çözeltisi ( $\mathrm{pH} 8.0$ ) içinde $734 \mathrm{~nm}$ 'de $0.9( \pm 0.2)$ absorbans değerini verecek şekilde seyreltilmiştir. $100 \mu \mathrm{L}$ seyreltilmiş ekstrakta $1 \mathrm{~mL}$ ABTS solüsyonu ilave edilerek karıştırılmış ve $1 \mathrm{dk}$ sonra spektrofotometre ile 734 nm'de absorbans ölçümü yapılmıştır. Toplam antioksidan kapasite mg Trolox eşdeğeri (TE)/100 mL numune olarak ifade edilmiştir. Trolox standart eğrisi 0.01-0.08 $\mathrm{mg} / \mathrm{mL}$ konsantrasyon aralığında elde edilmiştir $\left(\mathrm{R}^{2}=0.998\right)$.

CUPRAC metodu Apak ve ark. (2006) tarafindan belirtilen metoda uygun olarak gerçekleştirilmiştir. $100 \mu \mathrm{L}$ seyreltilmiş ekstrakt, toplam hacim $4.1 \mathrm{~mL}$ olacak şekilde, 1'er mL $10 \mathrm{mM}$ $\mathrm{CuCl}_{2}$, $7.5 \mathrm{mM}$ neokuproin, $1 \mathrm{M} \mathrm{NH}_{4} \mathrm{C}_{2} \mathrm{H}_{3} \mathrm{O}_{2}$ ve saf su ile karıştırılmış ve $30 \mathrm{dk}$ süre ile oda sıcaklığında inkübe edilmiştir. Daha sonra, spektrofotometre ile $450 \mathrm{~nm}$ 'de absorbans ölçümü yapılmış ve TAK değeri mg Trolox eşdeğeri (TE)/100 mL numune olarak ifade edilmiştir. Trolox standart eğrisi $0.1-0.8 \mathrm{mg} / \mathrm{mL}$ konsantrasyon aralığında elde edilmiştir $\left(\mathrm{R}^{2}=0.998\right)$.

\section{8. İstatistiksel Analiz}

Analizler 3 tekrarlı olarak temin edilen numunelerde 3 paralelli ölçümler yapılarak gerçekleştirilmiş ve analiz sonuçları ortalama \pm standart sapma şeklinde ifade edilmiştir. Veriler Minitab yazılımı (versiyon 19.2.0) kullanılarak tek yönlü ANOVA'ya tabi tutulmuş ve numuneler arasındaki farklılıkların belirlenmesinde Tukey testi uygulanmıştır $(\mathrm{p}<0.05)$.

\section{Araştırma Sonuçları ve Tartışma}

Bu çalışmada, ülkemizde geleneksel olarak üretimi yapılan ürünleri de içeren bazı siyah üzüm ve nar ürünlerinin TFEM, TFLM ve TMA miktarları ile 3 farklı metot (DPPH, ABTS, CUPRAC) kullanılarak ölçülen TAK değerlerini içeren antioksidan özellikleri belirlenmiş ve, aynı meyve grubu içerisinde, karşılaştırmalı olarak incelenmiştir. Siyah üzüm ürünleri ve nar ürünleri için elde edilen bulgular, sırasıyla, Tablo 1 ve Tablo 2'de verilmiştir. Sonuçlar, ürünlerin tüketildikleri haliyle gösterdikleri antioksidatif fonksiyonun değerlendirilmesi amacıyla, yaş madde bazında ifade edilmiştir. Bunun yanı sıra, ürünler arasındaki farklılıkların daha doğru bir şekilde yorumlanabilmesi için SÇKM miktarları da göz önünde bulundurulmuştur. 


\subsection{Siyah Üzüm Ürünlerinin Antioksidan Özellikleri}

Çalışma kapsamında analizlenen siyah üzüm ürünlerinden üzüm suyu, koruk suyu ve hardaliye için belirlenen TFEM, TFLM, TMA miktarları ile TAK değerleri, değişen sıralamalarda, en yüksek değerleri almış; bu ürünleri, tüm analizlerde, sırasıyla, üzüm pekmezi ve üzüm sirkesi ürünleri izlemiştir (Tablo 1).

Üzüm suyu, koruk suyu ve hardaliye ürünlerinin TFEM miktarları kendi aralarında karşılaştırıldığında, koruk suyu ve hardaliye için belirlenen TFEM miktarları (sırasıyla, 136.7 \pm 2.6 ve $147.5 \pm 16.0 \mathrm{mg} \mathrm{GAE} / 100 \mathrm{~mL}$ ) üzüm suyu için belirlenen TFEM miktarından $(102.8 \pm 14.6 \mathrm{mg}$ GAE/100 mL) yüksek çıkmıştır ve fark önemlidir $(p<0.05)$. Üzümün olgunluk derecesinin artışıyla TFEM miktarının azalış gösterdiği farklı araştırmacılar tarafından yapılan çalışmalarda ortaya konmuş (Cangi ve ark., 2011; Doshi ve ark., 2006; Jin ve ark., 2009; Navarro ve ark., 2008; Otağ, 2015); ve bu durum, kısmen, erken olgunlaşma dönemlerinde TFEM miktarına direkt etki eden yüksek tanen miktarının olgunlaşmaya bağlı olarak azalması ve özellikle meyve kabuğu ile çekirdekte yüksek miktarlarda bulunan fenolik bileşiklerin hasat yaklaştıkça yüzey-hacim oranının azalmasına bağlı olarak düşüş göstermesi ile ilişkilendirilmiştir (Otağ, 2015). Öte yandan, bu çalışmada test edilen üzüm suyu ve koruk suyu örnekleri arasında, şeker konsantrasyonunu belirlemek amaciyla ölçülen ve meyvenin olgunluk derecesinin bir göstergesi olarak kabul edilen (Otağ, 2015; Shakir ve Salih Rashid, 2019), suda çözünebilir kuru madde miktarı (SÇKM) ( ${ }^{\circ}$ Briks) açısından istatistiksel olarak önemli bir fark olmadığı tespit edilmiştir (Tablo 1). Koruk suyu için ölçülen ${ }^{\circ}$ Briks değeri (14.93 \pm 0.12$)$ farklı çalışmalarda siyah/kırmızı üzüm çeşitlerinden elde edilen koruk sularında ölçülen ${ }^{\circ}$ Briks değerlerinden (4.09-4.91 (Eddine ve ark. (2020); 4.5-7.5 (Hayoğlu ve ark. (2009); 3.87-5.15 (Otağ, 2015); 5.1-5.4 (Öncül ve Karabıyıklı (2015); 5 (Shakir ve Salih Rashid, 2019) daha yüksektir. Otağ (2015) siyah üzüm çeşitleri için koruk ile tam olgunluk arasındaki olgunlaşma aşaması olan "ben düşme" olgunlaşma aşamasındaki ${ }^{\circ}$ Briks değerlerini 8.6012.98 aralığında ölçmüştür. Bu çalışmada koruk suyu için ölçülen ${ }^{\circ}$ Briks değerleri ben düşme olgunlaşma aşamasındaki siyah üzüm çeşitleri için belirlenen ${ }^{\circ}$ Briks aralığı ile yakınlık göstermektedir. Benzer şekilde, siyah bir üzüm çeşidinin antioksidan özelliklerinin incelendiği başka bir çalışmada, ben düşme olgunlaşma aşamasındaki üzümler ile çalışılmış ve bu çalışmada koruk suyu için ölçülen SÇKM miktarı ile paralel olarak, şeker içeriği $143 \mathrm{~g} / \mathrm{L}$ olarak belirlenmiştir (Fia ve ark., 2020). Buna ek olarak, Otağ (2015)'ın çalışmasında, koruk aşamasında yeşil renkte olan siyah üzümlerin ben düşme aşamasında renk almaya başladığı gösterilmiştir. Ben düşme aşaması siyah üzümlerde kabukta antosiyanin birikimi nedeniyle renk dönüşümü olarak tanımlanmaktadır (Mateus ve ark., 2002). Bununla uyumlu olarak, bu çalışmada analizlenen koruk suyu da kırmızı renktedir. Buna karşın, üzüm suyu için ölçülen ${ }^{\circ}$ Briks değeri (13.77 \pm 0.06$)$ ise farklı çalışmalarda tam olgunluk derecesindeki siyah üzümlerin suyunda ölçülen ${ }^{\circ}$ Briks değerlerinin (22.20-22.30 (Cangi ve ark., 2011); 20.87$22.16^{\circ}$ Briks (Otağ, 2015)) altındadır, ve yine Otağ (2015) tarafindan ben düşme aşamasındaki siyah üzüm çeşitleri için belirlenen ${ }^{\circ}$ Briks aralığı (8.60-12.98) ile yakınlık göstermektedir. Ancak, üzümün SÇKM miktarını da içeren fizikokimyasal özellikleri, olgunlaşma derecesinin yanı sıra, asmanın genotipi, üzüm çeşidi, farklı çeşitlerin yetişme e-ISSN: 2148-2683 koșullarına değişen düzeyde hassasiyet göstermesi, hasat y1lı, çevresel stres gibi pek çok faktörden etkilenmektedir (Eddine ve ark., 2020; Cangi ve ark., 2011; Öncül ve Karabıyıklı, 2015). Türkmen Özen (2015) değişik yörelerden sağlanan 12 farklı siyah üzüm çeşidinin suyunda iki farklı yılda yapılan ölçümlerde ${ }^{\circ}$ Briks değerlerini ilk ölçüm yılı için 18.41-31.13 aralığında, diğer ölçüm yılı için ise 11.10-26.91 aralığında tespit etmiştir. Bu durumda, bu çalışmada üzüm suyu ve koruk suyu için ölçülen ${ }^{\circ}$ Briks değerleri, Türkmen Özen (2015)'in çalışmasında ilk ölçüm yılı için belirtilen değerler dikkate alındığında erken olgunlaşma dönemine denk gelirken; diğer ölçüm yılı için belirtilen değerler dikkate alındığında ise tam olgunluk dönemine denk gelmektedir. Bununla birlikte, koruk suyu doğal ekşi tadı ve düşük pH değeri ile tanımlanan (Eddine ve ark., 2020; Ergezer ve ark., 2018; Öncül ve Karabıyıklı, 2015; Shakir ve Salih Rashid, 2019) ve bu özelliği ile üzüm suyundan ayrılan bir üründür. Organik asit miktarı, olgunlaşmamış üzümlerin direkt tüketime sunulması veya ekşi tadın doğal bir kaynağı olan koruk suyu şeklinde kullanılmasında temel belirleyici özelliktir (Shakir ve Salih Rashid, 2019) ve olgunluğun artmasılla organik asit miktarı önemli ölçüde azalmaktadır (Cangi ve ark., 2011; Otağ, 2015). Doğal ekşi tadı gereği, bu çalışmada analiz edilen koruk suyu örneğinde de organik asit miktarının üzüm suyuna oranla daha yüksek olması, dolayısıyla, koruk suyu için kullanılan hammaddenin daha erken bir olgunlaşma aşamasında olması beklenmekte ve koruk suyu ve üzüm suyu örneklerinin SÇKM miktarlarının istatistiksel olarak karşılaştırılabilir olmasının farklı üzüm çeşitlerinin kullanımı, farklı hasat dönemlerindeki üzümlerden elde edilmiş olmaları, farklı çevresel etmenlerden etkilenmiş olmaları gibi faktörlerden kaynaklanabileceği düşünülmektedir. Buna ek olarak, koruk suyu ve üzüm suyu üretimi için kullanılan üzümlerin, ben düşme ile olgunluk aşamaları arasında geçen yaklaşık bir aylık sürenin (Cangi ve ark., 2011; Otağ, 2015), sırasıyla, erken ve geç dönemlerinde toplanmış olma ihtimalleri de göz önünde bulundurularak bu ayrıntının da ürünlerin olgunluk derecesi üzerinde etkili olmuş olabileceği değerlendirilmektedir. Cangi ve ark. (2011) 2 farklı siyah üzüm çeşidi için ben düşme ile hasat dönemi arasındaki 4-5 haftada SÇKM miktarı değişimini haftalık olarak incelemişler ve çeşitlerden biri için bu aralığı 14.90 ile $22.20^{\circ}$ Briks, diğer çeşit için ise 11.10 ile $22.30^{\circ}$ Briks aralığında tespit etmişlerdir. Bu veriler, koruk suyu üretiminde kullanılan ve daha erken bir olgunlaşma döneminde olduğu öngörülen üzüm çeşidinin, üzüm suyu üretiminde kullanılan ve daha geç bir olgunlaşma döneminde olduğu öngörülen üzüm çeşidi ile benzer SÇKM miktarına sahip olabileceği görüşüyle uyuşmaktadır. Koruk suyu ve üzüm suyunun SÇKM miktarları arasında önemli bir fark bulunmezken, koruk suyunda ölçülen yüksek TFEM miktarı üzümün olgunluk derecesinin artışıyla TFEM miktarının azalış gösterdiği bulgusuyla (Doshi ve ark., 2006; Jin ve ark., 2009; Navarro ve ark., 2008; Otağ, 2015) da örtüşmektedir ve yapılan değerlendirmeleri desteklemektedir. Öte yandan, olgun koyu renkli üzümlerden elde edilen bir ürün olan hardaliyenin TFEM miktarının üzüm suyu için ölçülen TFEM miktarından önemli ölçüde yüksek olması $(p<0.05)$ farklı şekillerde açıklanabilmektedir. Laktik asit fermantasyonundan elde edilen bir ürün olan hardaliye (Arıcı ve Coşkun, 2001) ile benzer şekilde üzüm suyunun probiyotik laktik asit bakterileri ile fermantasyonu sonucu fenolik madde miktarında artış tespit edilmiş ve bu durum, probiyotik aktivitesi sonucu tanenlerin degradasyonu ve yüksek oranda serbest hidroksil grubu içeren bileşiklerin ortaya çıkması ile 
European Journal of Science and Technology

Tablo 1. Siyah Üzüm Ürünlerinin Suda Çözünür Kuru Madde (SÇKM), Toplam Fenolik Madde (TFEM), Toplam Flavonoid Madde (TFLM), Toplam Monomerik Antosiyanin (TMA) ve Toplam Antioksidan Kapasite (TAK) Değerleri

\begin{tabular}{l|c|c|c|c|c}
\hline Analiz & Üzüm Suyu & Koruk Suyu & Üzüm Sirkesi & Hardaliye & Üzüm Pekmezi \\
\hline SÇKM ('Briks) & $13.77 \pm 0.06 \mathrm{c}$ & $14.93 \pm 0.12 \mathrm{c}$ & $1.83 \pm 0.06 \mathrm{~d}$ & $24.27 \pm 0.12 \mathrm{~b}$ & $60.67 \pm 1.15 \mathrm{a}$ \\
\hline TFEM (mg GAE/100 mL numune) & $102.8 \pm 14.6 \mathrm{~b}$ & $136.7 \pm 2.6 \mathrm{a}$ & $24.6 \pm 4.1 \mathrm{c}$ & $147.5 \pm 16.0 \mathrm{a}$ & $87.7 \pm 13.9 \mathrm{~b}$ \\
\hline TFLM (mg KE/ $100 \mathrm{~mL}$ numune) & $119.6 \pm 12.7 \mathrm{a}$ & $115.1 \pm 15.1 \mathrm{a}$ & $32.1 \pm 4.2 \mathrm{~b}$ & $101.6 \pm 15.0 \mathrm{a}$ & $49.4 \pm 3.1 \mathrm{~b}$ \\
\hline TMA $(\mu \mathrm{g}$ M3GE/100 mL numune) & $7795.3 \pm 392.6 \mathrm{a}$ & $1121.4 \pm 115.5 \mathrm{c}$ & $101.3 \pm 6.2 \mathrm{~d}$ & $2534.5 \pm 84.3 \mathrm{~b}$ & $131.1 \pm 18.9 \mathrm{~d}$ \\
\hline TAK $(\mathrm{mg}$ TE/100 mL numune) & & & & & \\
DPPH & $601.6 \pm 58.5 \mathrm{a}$ & $484.7 \pm 40.4 \mathrm{~b}$ & $75.1 \pm 7.8 \mathrm{c}$ & $602.3 \pm 55.8 \mathrm{a}$ & $135.8 \pm 6.5 \mathrm{c}$ \\
ABTS & $568.5 \pm 9.9 \mathrm{a}$ & $479.7 \pm 36.2 \mathrm{~b}$ & $125.3 \pm 12.0 \mathrm{e}$ & $396.7 \pm 12.0 \mathrm{c}$ & $206.6 \pm 16.6 \mathrm{~d}$ \\
CUPRAC & $1575.8 \pm 38.7 \mathrm{a}$ & $1406.6 \pm 38.9 \mathrm{a}$ & $221.9 \pm 19.5 \mathrm{c}$ & $1607.8 \pm 268.9 \mathrm{a}$ & $994.1 \pm 42.5 \mathrm{~b}$ \\
\hline
\end{tabular}

Bu tabloda gösterilen veriler 3 tekrarlı olarak temin edilen numunelerde 3 paralelli olarak yapılan ölçümlerin ortalama \pm standart sapma değerleridir. Satırlardaki farklı harfler istatistiksel olarak önemli farklılıkları temsil etmektedir $(\mathrm{p}<0.05)$.

ilişkilendirilmiştir (Khanniri ve ark., 2018). Öte yandan, toplam fenolik madde analizi için uygulanan Folin-Ciocalteu metodu sadece fenolik bileşenlere özgü bir test olmayıp, şekerler, askorbik asit, sitrik asit ve diğer organik asitler, aromatik aminler, sülfür dioksit gibi indirgen bileşenleri de ölçerek, TFEM miktarının olduğundan daha yüksek çıkmasına neden olabilmektedir (Capanoglu ve ark., 2018). Hardaliyenin SÇKM miktarının (24.27 $\pm 0.12 \quad{ }^{\circ}$ Briks), daha yüksek şeker konsantrasyonu ve üzüm suyundan farklı olarak içerdiği laktik asit ile ilişkili olarak, üzüm suyunun SÇKM miktarından $\left(13.77 \pm 0.06{ }^{\circ} \mathrm{Briks}\right)$ istatistiksel olarak daha yüksek olması $(\mathrm{p}<0.05)$ (Tablo 1), bu bileşenlerin hardaliyede TFEM miktarının olduğundan daha yüksek ölçülmesine katkıda bulunmuş olabilecekleri ile ilişkilendirilmektedir. Bununla birlikte, ürünlerin üretiminde kullanılan farklı üzüm çeşitlerinin de ölçülen TFEM miktarları üzerinde doğrudan etkili olduğu göz önünde bulundurulmalıdır (Cangi ve ark., 2011; Coşkun ve ark., 2018; Faikoğlu, 2014; Otağ, 2015).

Üzüm suyu, koruk suyu ve hardaliyenin TMA miktarları karşılaştırıldığında, üzüm suyunun en yüksek değeri aldığı $(7795.3 \pm 392.6 \mu \mathrm{g} \mathrm{M} 3 \mathrm{GE} / 100 \mathrm{~mL})$ ve onu, sirasiyla, hardaliye ve koruk suyunun (sirasiyla, $2534.5 \pm 84.3$ ve $1121.4 \pm 115.5 \mu \mathrm{g}$ $\mathrm{M} 3 \mathrm{GE} / 100 \mathrm{~mL}$ ) izlediği tespit edilmiş ve ürünler arasındaki farkın önemli olduğu hesaplanmıştır $(p<0.05)$. Koyu renkli üzüm çeşitlerinde ben düşme olgunlaşma aşamasında başlayan antosiyanin birikimi tam olgunluk aşamasına kadar artarak devam etmektedir (Cangi ve ark., 2011; Otağ, 2015). Üzüm suyu ile koruk suyunun TMA miktarları arasında yaklaşık 7 kat oranında bir fark belirlenmiştir. Benzer şekilde, Cangi ve ark. (2011), analizledikleri siyah bir üzüm çeşidinde ben düşme olgunlaşma aşamasından tam olgunlaşmaya kadar geçen sürede toplam antosiyanin miktarında yaklaşık 4 katlık bir artış gözlemlemişlerdir. Bu çalışmada da koruk suyu ile üzüm suyunun TMA miktarları arasındaki farkın, koruk suyu üretiminde ben düşme olgunlaşma aşamasının daha erken evrelerindeki üzümlerin kullanılmış olması ve üzüm çeşitlerinin farklılığından kaynaklandığı düşünülmektedir. Buna karşın, üzümün son olgunluk aşamasında antosiyanin birikimi stabil hale gelmekte ve aşırı olgunlukla birlikte antosiyanin miktarı azalmaktadır (Mateus ve ark., 2002). Antosiyanin stabilitesinin ürünün $\mathrm{pH}$ değeri, şeker içeriği, başlangıç antosiyanin konsantrasyonu, prosesi sırasında uygulanan parametreler ve depolama koşullarından (sıcaklık, oksijen, 1şık, vb.) önemli derecede etkilendiği bilinmektedir (Rein, 2005). Bu bilgiler 1şığında, üzüm suyunun TMA miktarının hardaliye için ölçülen TMA miktarından önemli e-ISSN : 2148-2683 derecede yüksek olması $(\mathrm{p}<0.05)$ üretimde kullanılan üzüm çeşidi, üzümlerin olgunluk derecesi, ürün prosesi ve farklı depolama koşullarının uygulanması gibi pek çok faktör ile iliş̧kilendirilebilir (Aşkın, 2019; Coşkun ve ark., 2018; Türkmen Özen, 2015).

Toplam antioksidan kapasite ölçümü için uygulanan DPPH, ABTS ve CUPRAC analiz metotlarının tümünde en yüksek TAK değerleri, TFEM, TFLM ve TMA miktarı için elde edilen verilerle de uyumlu olarak, üzüm suyu, koruk suyu ve hardaliye ürünlerinde tespit edilmiştir. Bu üç ürünün uygulanan farklı antioksidan kapasite ölçüm metotları için farklı sıralamalar vermesi metot prensiplerinin farklıllı̆ı ile ilişkilendirilebilir.

Üzüm sirkesinin tüm analizlerde en düşük değeri vermesi, birincil olarak, antioksidan bileşenlerin de içinde olduğu, SÇKM miktarının çok düşük olması (1.83 \pm 0.06$)$ (Tablo 1) ile ilişkilendirilmektedir. $\mathrm{Bu}$ çalışmada analizlenen üzüm sirkesinin hammaddesi olan koruk için, Otağ (2015) yaptığı çalışmada, takip eden olgunlaşma aşamalarına göre daha yüksek TFEM miktarı belirlemiştir. Cangi ve ark. (2011) olgunlaşma ile toplam fenol ve antioksidan miktarının azaldığını tespit etmişlerdir. Bakır ve ark. (2016) konsantre üzüm suyundan alkol ve asetik asit fermantasyonu ile elde edilen üzüm sirkesinde, TFEM, TFLM, TAK'de kuru madde bazında bir azalma tespit etmemişlerdir. Buna karşın, üzüm pekmezi, analiz edilen üzüm ürünleri arasında en yüksek SÇKM miktarına $(60.67 \pm 1.15) \quad(\mathrm{p}<0.05) \quad$ (Tablo 1) sahip olmasına rağmen, üzüm sirkesinden sonra en düşük değerleri vermiştir. Üzüm suyu için ölçülen TMA miktarı ve TAK değerleri üzüm pekmezi için ölçülen değerlerden istatistiksel olarak önemli derecede yüksektir $(p<0.05)$. Geleneksel yönteme göre yapılan pekmez üretiminde şıranın açık kazanlarda yüksek sicaklıkta $\left(100-110^{\circ} \mathrm{C}\right)$ kaynatılmasını içeren evaporasyon işlemi uygulanmaktadır (Batu, 2020). Siyah üzümde öne çıkan antioksidan madde grubu olan antosiyaninlerin oksijen varlığı ve yüksek proses sıcaklıklarında önemli ölçüde kayba uğradığı daha önce de rapor edilmiştir (Jackman ve ark., 1987). Türkmen Özen (2015), pekmez üretimi ile benzer basamakların (durultma, filtrasyon, evaporasyon) uygulandığı siyah üzüm suyunun konsantreye işlenmesi sırasında da monomerik antosiyanin miktarı ve TAK değerlerinde istatistiksel olarak önemli bir azalış tespit etmiştir. 


\subsection{Nar Ürünlerinin Antioksidan Özellikleri}

Çalışma kapsamında analiz edilen nar ürünleri arasında, sırasıyla, nar pekmezi, nar ekşisi ve fermente nar ekşisi en yüksek SÇKM miktarına (sırasıyla, 71.33 $\pm 3.21{ }^{\circ}$ Briks, $63.67 \pm 2.31{ }^{\circ}$ Briks ve $63.00 \pm 5.57{ }^{\circ}$ Briks) sahip olmaları ile uyumlu olarak, daha düşük SÇKM miktarına sahip olan nar suyu $\left(15.73 \pm 0.12^{\circ}\right.$ Briks $)$ ve nar sirkesine $\left(2.97 \pm 0.06{ }^{\circ}\right.$ Briks $)$ oranla daha yüksek antioksidan madde miktarı ve antioksidan aktivite göstermişlerdir (Tablo 2).

En yüksek antioksidan değerlerin ölçüldüğü nar ekşisi, fermente nar ekşisi ve nar pekmezi ürünleri kendi aralarında karşılaştırıldığında; fermente nar ekşisi, TFEM (1101.4 \pm 68.3 mg GAE/100 mL), TFLM (147.5 $\pm 1.9 \mathrm{mg} \mathrm{KE} / 100 \mathrm{~mL})$, TMA (2514.1 $\pm 409.3 \mu \mathrm{g}$ C3GE/100 mL) ve TAK ölçümü için uygulanan ABTS $(2115.2 \pm 141.4 \mathrm{mg}$ TE/100 mL) ve CUPRAC $(6076.2 \pm 629.8 \mathrm{mg} \mathrm{TE} / 100 \mathrm{~mL})$ metotlarının hepsinde en yüksek değeri almıştır ve CUPRAC metodu hariç, diğer sayılan metotlarda, onu izleyen nar ürünü ile arasındaki fark önemlidir $(\mathrm{p}<0.05)$. Öte yandan, nar ekşisinin TFEM $(402.9 \pm 8.4 \mathrm{mg}$ GAE/100 mL) ve TMA (1415.7 $\pm 240.7 \mu \mathrm{g}$ C3GE/100 mL) miktarları nar pekmezi için ölçülenlerden (sırasıyla, $349.4 \pm 8.4$ mg GAE/100 mL ve $1412.0 \pm 238.9 \mu \mathrm{g} \mathrm{C} 3 \mathrm{GE} / 100 \mathrm{~mL})$ daha yüksek olmakla birlikte, fark istatistiksel olarak önemli çıkmamıştır ( $p>0.05)$. ABTS ve CUPRAC ile belirlenen TAK sonuçlarına bakıldığında ise, nar ekşisinin (sırasıyla, $1574.9 \pm 80.3$ ve $5361.1 \pm 172.7 \mathrm{mg} \mathrm{TE} / 100 \mathrm{~mL}$ ) nar pekmezinden (sirasiyla, $1136.9 \pm 49.4$ ve $3413.9 \pm 324.4 \mathrm{mg}$ TE/100 mL) daha yüksek değerler verdiği tespit edilmiştir ve aradaki fark önemlidir $(\mathrm{p}<0.05)$. Diğer metotlardan farklı olarak, DPPH metodunda en yüksek TAK değeri nar pekmezi (1961.5 $\pm 15.0 \mathrm{mg}$ TE/100 mL) için belirlenmiştir. Aynı metotta ikinci en yüksek değeri alan fermente nar ekşisi (1925.2 \pm 19.1 mg TE/100mL) ile nar pekmezi arasında önemli bir fark belirlenmezken ( $\mathrm{p}>0.05)$; nar ekşisi diğer ikisinden daha düşük bir değer $(1618.3 \pm 22.9 \mathrm{mg} \mathrm{TE} / 100 \mathrm{~mL})$ vermiştir $(\mathrm{p}<0.05)$. DPPH metodu ile sadece lipofilik yapıdaki antioksidanlar belirlenebilirken, ABTS ve CUPRAC metotları ile hem lipofilik hem de hidrofilik yapıdaki antioksidanlar belirlenebilmektedir (Apak ve ark., 2007). DPPH metodunun diğer metotlardan ayrılması, kısmen, çalışma prensibindeki farklılıklar ile ilişkilendirilebilir.

Aynı yerel üreticiden temin edilen nar ekşisi ve fermente nar ekşisi ürünleri aynı üretim basamaklarına tabi tutulmuş; farklı olarak, fermente nar ekşisi 1 yıl süre ile fermantasyona bırakılmıştır (Şekil 2). Uygulanan bu fermantasyon basamağı, nar ekşisi ile karşılaştırıldığında, fermente nar ekşisinin TFEM, TFLM, TMA miktarı ve TAK (DPPH ve ABTS metotları) değerlerinde istatistiksel olarak önemli bir artış (sırasıyla, $\% 173, \% 34, \% 78, \% 19$ ve \%34 artış) olmasına katkı sağlamıştır $(p<0.05)$. Buna karşın, başka bir çalışmada, Mousavi ve ark. (2013), nar suyu konsantresinin laktik asit bakterileriyle fermantasyonu sonucu, nar suyundaki temel fenolikler olan antosiyanin grubu bileşenler ile elajik asit miktarlarında önemli bir düşüş olduğunu tespit etmişlerdir. Bununla birlikte, aynı çalışmada, laktik asit fermantasyonu ile nar suyunun antioksidan kapasitesinde artış gözlenmiştir. $\mathrm{Bu}$ durum, laktik asit bakterilerinin antosiyanin yapısındaki şeker kısmını kendi metabolizmaları için karbonhidrat kaynağı olarak kullanmaları sonucu aglikon formdaki antosiyanidinlerin açı̆̆a çıkması ile hem antosiyanin miktarında düşüş hem de aglikonların (ve muhtemel metabolitlerinin) daha yüksek antioksidan aktivite göstermesi sonucu antioksidan kapasitede artış sağlamış olabileceği şeklinde yorumlanmıştır (Mousavi ve ark., 2013). Bu konudaki farklı bulguların daha doğru bir şekilde değerlendirilebilmesi için daha fazla sayıda çalışma yapılması ve antioksidan bileşenlerdeki değişimin bireysel olarak incelenmesi gereklidir. Yine benzer proses aşamalarından geçen nar ekşisi ve nar pekmezi ürünleri arasındaki fark, üretimde hammadde olarak ekşi veya tatlı nar genotiplerine ait meyvelerin kullanılmasından kaynaklanmaktadır. Eroğul ve ark. (2017) ekşi ve tatlı nar genotiplerine ait meyvelerin TFEM miktarı ve TAK değerlerini karşılaştırdıkları çalışmalarında ekşi nar genotipinin her iki ölçüm için de daha yüksek sonuçlar verdiğini tespit etmiş, ve bu durumu, genotip özelliği ile ilişkilendirmişlerdir. Başka bir çalışmada, benzer şekilde, ekşi nar genotipine ait meyvelerin toplam fenolik ve toplam antosiyanin miktarları ile toplam antioksidan kapasitelerinin tatlı nar genotiplerine ait meyvelerden daha yüksek olduğu rapor edilmiştir (Sepulveda ve ark., 2010). Bu çalışmada da, nar ekşisinin nar pekmezinden daha yüksek TFEM $(p>0.05)$, TMA $(p>0.05)$ ve TAK (ABTS $(p<0.05)$ ve CUPRAC $(p<0.05))$ değerlerini vermesi direkt olarak hammaddenin kendisi ile ilişkilendirilebilir. Ayrıca, ürünlerin temin edildiği üreticilerden edinilen bilgiler doğrultusunda, nar pekmezi üretiminde kaynatma işlemi uygulanmış; buna karşın, nar ekşisi üretiminde kaynatma olmadan, daha düşük sıcaklıkta, buharlaştırma yapılmıştır. Nar pekmezi üretiminde daha yüksek sıcaklıklara çıkılmış olmasının antioksidan madde miktarı ve antioksidan aktivitede daha yüksek kayıplara neden olmuş olabileceği de değerlendirilmektedir.

Nar pekmezi ve nar ekşisi için ölçülen antioksidan analiz değerleri nar suyu için ölçülen değerlerden yüksek olmakla birlikte, aradaki fark, her iki ürün için, TMA miktarı ve, sadece nar pekmezi için, ABTS ve CUPRAC metotları ile belirlenen TAK değerleri için önemli çıkmamıştır $(p>0.05)$. Nar suyu üretiminde mayhoş (ekşi-tatlı) nar genotipine ait meyveler kullanılmaktadır (Baysal ve Taştan, 2018). Eroğul ve ark. (2017) mayhoş nar genotipine ait meyvelerin TFEM miktarı ve TAK değerlerinin ekşi nar genotipine ait meyvelerinkinden daha düşük, tatlı nar genotipine ait meyvelerinkinden ise daha yüksek olduğunu belirlemişlerdir. Başka bir çalışmada, ekşi nar genotipine ait meyvelerden elde edilen nar sularındaki TMA miktarları, genel olarak, ekşi-tatlı (mayhoş) nar genotipine ait meyvelerden elde edilen nar sularındaki TMA miktarlarından daha yüksek bulunmuştur (Türkyılmaz, 2013). Bununla birlikte, nar ekşisi ve nar pekmezi için ölçülen SÇKM miktarlarının nar suyundaki SÇKM miktarından önemli derecede yüksek olduğu $(\mathrm{p}<0.05)$ da göz önünde bulundurulduğunda pekmez/ekși üretiminin özellikle antosiyanin madde miktarında düşüşe neden olduğu sonucuna varılmaktadır. Bu durum, üzüm pekmezi üretiminde de olduğu gibi, proses sırasında antosiyaninlerin yüksek sıcaklık ve oksidasyona bağlı olarak kayba uğraması ve narda başlıca antioksidan grubu olan antosiyaninlerdeki bu kaybın TAK değerinde de düşüşle sonuçlanması şeklinde yorumlanmaktadır. Aradaki farkın üzüm pekmezindeki kadar dramatik olmaması, meyve çeşitlerinin farklılığı ile ilişkilendirilebilir. Pekmezden farklı olarak, nar ekşisinin TAK (ABTS ve CUPRAC metotları) değerlerinin nar suyundan istatistiksel olarak yüksek $(\mathrm{p}<0.05)$ olması ise, nar ekşisinin, yukarıda açıklandığı üzere, hammadde ve üretim koşullarındaki farklılıklardan dolayı, pekmeze oranla, daha yüksek antioksidan madde miktarı ve antioksidan kapasiteye sahip 
European Journal of Science and Technology

Tablo 2. Nar Ürünlerinin Suda Çözünür Kuru Madde (SÇKM), Toplam Fenolik Madde (TFEM), Toplam Flavonoid Madde (TFLM), Toplam Monomerik Antosiyanin (TMA) ve Toplam Antioksidan Kapasite (TAK) Değerleri

\begin{tabular}{l|c|c|c|c|c}
\hline Analiz & Nar Suyu & Nar Ekşisi & $\begin{array}{c}\text { Fermente Nar } \\
\text { Ekşisi }\end{array}$ & Nar Sirkesi & Nar Pekmezi \\
\hline SÇKM $\left({ }^{\circ}\right.$ Briks $)$ & $15.73 \pm 0.12 \mathrm{c}$ & $63.67 \pm 2.31 \mathrm{ab}$ & $63.00 \pm 5.57 \mathrm{~b}$ & $2.97 \pm 0.06 \mathrm{~d}$ & $71.33 \pm 3.21 \mathrm{a}$ \\
\hline TFEM $(\mathrm{mg}$ GAE$/ 100 \mathrm{~mL}$ numune) & $192.1 \pm 13.8 \mathrm{c}$ & $402.9 \pm 8.4 \mathrm{~b}$ & $1101.4 \pm 68.3 \mathrm{a}$ & $75.6 \pm 6.8 \mathrm{~d}$ & $349.4 \pm 8.4 \mathrm{~b}$ \\
\hline TFLM $(\mathrm{mg} \mathrm{KE} / 100 \mathrm{~mL}$ numune) & $69.2 \pm 4.9 \mathrm{c}$ & $110.0 \pm 1.7 \mathrm{~b}$ & $147.5 \pm 1.9 \mathrm{a}$ & $25.2 \pm 1.0 \mathrm{~d}$ & $115.9 \pm 1.7 \mathrm{~b}$ \\
\hline TMA $(\mu \mathrm{g}$ C3GE/100 mL numune) & $820.1 \pm 75.6 \mathrm{bc}$ & $1415.7 \pm 240.7 \mathrm{~b}$ & $2514.1 \pm 409.3 \mathrm{a}$ & $393.4 \pm 55.8 \mathrm{c}$ & $1412.0 \pm 238.9 \mathrm{~b}$ \\
\hline TAK $(\mathrm{mg}$ TE/100 mL numune) & & & & & \\
DPPH & $1257.1 \pm 38.7 \mathrm{c}$ & $1618.3 \pm 22.9 \mathrm{~b}$ & $1925.2 \pm 19.1 \mathrm{a}$ & $160.8 \pm 7.4 \mathrm{~d}$ & $1961.5 \pm 15.0 \mathrm{a}$ \\
ABTS & $915.9 \pm 112.5 \mathrm{c}$ & $1574.9 \pm 80.3 \mathrm{~b}$ & $2115.2 \pm 141.4 \mathrm{a}$ & $192.7 \pm 4.1 \mathrm{~d}$ & $1136.9 \pm 49.4 \mathrm{c}$ \\
CUPRAC & $3060.5 \pm 79.4 \mathrm{~b}$ & $5361.1 \pm 172.7 \mathrm{a}$ & $6076.7 \pm 629.8 \mathrm{a}$ & $397.6 \pm 62.4 \mathrm{c}$ & $3413.9 \pm 324.4 \mathrm{~b}$ \\
\hline
\end{tabular}

Bu tabloda gösterilen veriler 3 tekrarlı olarak temin edilen numunelerde 3 paralelli olarak yapılan ölçümlerin ortalama \pm standart sapma değerleridir. Satırlardaki farklı harfler istatistiksel olarak önemli farklılıkları temsil etmektedir $(p<0.05)$.

olmasıyla ilişkilendirilebilir. Bu çalışma ile uyumlu olarak, Orak (2009), nar suyu ile geleneksel yöntemle üretilen nar ekşisinin TFEM ve TMA miktarı ile antioksidan aktivitelerini karşılaştırdıkları çalışmalarında, nar ekşisinin nar suyundan daha yüksek TFEM miktarı ve antioksidan aktiviteye sahip olduğunu tespit etmişler; buna karşın, nar ekşisinde TMA miktarını ölçememişlerdir. Bu durum, geleneksel nar ekşisi yapımında yüksek sıcaklıkta uzun süreli olarak gerçekleştirilen ısıl işlem uygulamasının antosiyaninlerin degradasyonuna sebep olduğu şeklinde yorumlanmıştır (Orak, 2009).

Nar sirkesinin diğer nar ürünlerine göre daha düşük değerler vermesi öncelikle daha düşük SÇKM miktarına $(\mathrm{p}<0.05)$ sahip olması ile ilişkilendirilmektedir. Bununla birlikte, nar suyunun fermantasyonu sonucu özellikle antosiyanin ve tanen miktarındaki azalmalar ile birlikte antioksidan aktivitenin azaldığ belirtilmiştir (Mena ve ark., 2012; Zhuang ve ark., 2011). Benzer şekilde, Ordoudi ve ark. (2014) nar suyu ile nar sirkesinin antioksidan aktivitelerini karşılaştırdıkları çalışmalarında nar sirkesinde daha düşük antioksidan aktivite tespit etmişlerdir.

\section{Sonuç}

Bu çalışmada, ülkemizde geleneksel olarak üretimi yapılan ürünleri de içeren bazı siyah üzüm ve nar ürünlerinin, tüketildikleri haliyle (yaş madde bazında), sağladıkları antioksidan madde miktarı ve gösterdikleri antioksidan aktivite, aynı meyve grubu bazında, karşılaştırmalı olarak incelenmiş̧ir. Elde edilen veriler, üzüm ürünleri arasından, üzüm suyu, koruk suyu ve hardaliyenin; nar ürünleri arasından ise fermente nar ekşisi, nar ekşisi ve nar pekmezinin birbirleriyle daha yakın ve daha yüksek değerler verdiklerini göstermiştir. Üzüm suyu, koruk suyu ve hardaliye ürünlerinin birbirleri içinde gösterdikleri farklılıkların, öncelikli olarak, üretimlerinde kullanılan üzüm çeşitlerinin farklı olması ve/veya farklı olgunlaşma aşamasındaki üzümlerden üretilmiş olmalarından kaynaklandığı değerlendirilmiştir. Benzer şekilde nar ekşisi ve nar pekmezi ürünleri arasındaki farklılıklar da, kısmen, geleneksel üretim koşullarında farklı nar genotiplerine ait meyvelerin kullanılması ile ilişkilendirilmiştir. Meyve çeşidi/genotipi, olgunlaşma aşaması ve SÇKM miktarları arasındaki farklılıklar/benzerlikler göz önünde bulundurularak, hardaliye üretiminde fermantasyon aşamasının analizlenen antioksidan özellikler üzerine önemli bir etkisinin olmadığı; buna karşın fermente nar ekşisi üretiminde uygulanan fermantasyon basamağının ise, nar ekşisine oranla, antioksidan madde miktarı ve antioksidan aktivitede önemli bir artış olmasına katkıda bulunduğu sonucuna varılmıştır. Ayrıca, nar ürünleri için ölçülen değerler SÇKM miktarları ile de parallellik gösterirken; üzüm ürünleri arasında, en yüksek SÇKM miktarına $(p<0.05)$ sahip olan üzüm pekmezinin, en düşük SÇKM miktarına $(\mathrm{p}<0.05)$ sahip olan üzüm sirkesinden sonra en düşük değerleri vermesi, geleneksel pekmez üretim aşamalarının, üzümde başta antosiyanin grubu bileşenler olmak üzere, antioksidan madde miktarı ve dolayısıyla, antioksidan kapasitede önemli bir düşüşe neden olduğu şeklinde yorumlanmıştır. Her iki meyve grubu için sirke ürünlerinin en düşük antioksidan değerlerini vermesi, birincil olarak, en düşük SÇKM miktarlarına sahip olmalarından kaynaklanmaktadır. Bu durum, ürünlerin tüketildikleri haliyle gösterdikleri antioksidatif fonksiyonda belirleyici olmaktadır. Bu çalışmada analizlenen ürünler arasında her ne kadar hammadde (meyve çeşidi/genotipi) farklılıkları olsa da, elde edilen veriler ışığında yapılan karşılaştırmalar, bu konudaki literatür bilgileri ile uyumluluk göstermektedir ve bu ürün gruplarının birlikte karşılaştırıldığı bilinen başka bir çalışma olmaması nedeniyle, bundan sonra yapılacak çalışmalar için de öncülük edeceği düşünülmektedir. Ancak, gelecekte yapılacak çalışmalarda, analizi yapılan bu ürünlerin, hammadde farklılıklarının ortadan kaldırıldığı ve kontrollü proses koşullarının uygulandığı şartlarda üretilmesi, daha doğru karşılaştırmalar yapılabilmesi için gereklilik teşkil etmektedir. Ayrıca, gelecekte yapılacak çalışmalarda bu ürünlerdeki antioksidan bileşenlerin biyoyararlılıklarının karşılaştırılması, siyah üzüm ve nar meyvelerindeki antioksidan bileșenlerin biyoyararlll l̆ğ 1 üzerine farklı proses koşullarının ve farklı proses aşamaları sonucu elde edilen farklı gida matrikslerinin etkisinin ortaya konması ve konuyla ilgili literatüre sağlayacağı katkı açısından önemlidir.

\section{Kaynakça}

Apak, R., Güçlü, K., Demirata, B., Özyürek, M., Çelik, S.E., Bektaşoğlu, B., Berker, K.I., \& Özyurt, D. (2007). Comparative Evaluation of Various Total Antioxidant Capacity Assays Applied to Phenolic Compounds with the CUPRAC Assay. Molecules, 12(7), 1496-1547.

Apak, R., Guclu, K., Ozyurek, M., Karademir, S. E., \& Ercag, E. (2006). The Cupric Ion Reducing Antioxidant Capacity and Polyphenolic Content of Some Herbal Teas. International Journal of Food Sciences and Nutrition, 57, 292-304. 
Arıcı, M., \& Coşkun, F. (2001). Hardaliye: Fermented Grape Juice As A Traditional Turkish Beverage. Food Microbiology, 18, 417-421.

Aşkın, B. (2019). Farklı Sıcaklıkların Hardaliyenin Depolama Stabilitesi Üzerine Etkisi. Harran Tarım ve Gıda Bilimleri Dergisi, 23(1), 13-21.

Aydoğdu, H., Yıldırım, S., Halkman, A., \& Durgun, T. (2014). A Study on Production and Quality Criteria of Hardaliye; A Traditional Drink from Thrace Region of Turkey. Gida, 39(3), 139-145.

Bakır, S., Toydemir, G., Boyacıŏlu, D., Beekwilder, J., \& Çapanoglu E. (2016). Fruit Antioxidants during Vinegar Processing: Changes in Content and in vitro BioAccessibility. International Journal of Molecular Sciences, 17(10), 1658. https://doi.org/10.3390/ijms17101658

Batu, A. (2020). Gastronomi ve Moleküler Gastronomi Açısından Üzüm Pekmezi. Aydın Gastronomy, 4(1), 35-44.

Baysal, T., \& Taştan, Ö. (2018). Nar Ürünleri ve Üretimi. In Nar Sağlıkta Yıldız, E. Akçiçek, H. Kayalar, \& S. Ötleş, Editors., Türkiye: Gece Yayınları.

Cangi, R., Saraçoğlu, O., Uluocak, E., Kılıç, D., \& Şen, A. (2011). Kazova (Tokat) Yöresinde Yetiştirilen Bazı Şaraplık Üzüm Çeşitlerinde Olgunlaşma Sırasında Meydana Gelen Kimyasal Değişmeler. Journal of the Institute of Science and Technology, 1(3), 9-14.

Cantos, E., Espin, J .C., \& Tomas-Barberan F. A. (2002). Varietal differences among the polyphenol profiles of seven table grape cultivars studied by LC-DAD-MS-MS. Journal of Agricultural and Food Chemistry, 50, 5691-5696.

Cemeroğlu, B. (2007). Gıda Analizleri. G1da Teknolojisi Derneği Yayınları, Ankara.

Cory, H., Passarelli, S., Szeto, J., Tamez, M., \& Mattei, J. (2018). The Role of Polyphenols in Human Health and Food Systems: A Mini-Review. Frontiers in Nutrition, 5, 87. https://doi.org/10.3389/fnut.2018.00087.

Coşkun, F., Arıcı, M., Gülcü, M., Çelikyurt, G., \& Mırık, M. (2018). Physicochemical, Functional and Microbiological Properties of Hardaliye Beverages Produced from Different Grapes and Collected from Different Households. Journal of Agricultural Sciences, 24(2), 278-285.

Çapanoglu, E., Kamiloğlu, S., Özkan, G., \& Apak, R. (2018). Evaluation of Antioxidant Activity/Capacity Measurement Methods for Food Products. In Measurement of Antioxidant Activity and Capacity: Recent Trends and Applications, R. Apak, E. Capanoglu, \& F. Shahidi, Editors., Chicester, United Kingdom: John Wiley \& Sons Ltd., p. 273-286.

Doshi, P., Adsule, P., \& Banerjee, K. (2006). Phenolic Composition and Antioxidant Activity in Grapevine Parts and Berries (Vitis vinifera L.) cv. Kishmish Chornyi (Sharad Seedless) During Maturation. International Journal of Food Science and Technology, 41(Supplement 1), 1-9.

Eddine, N. S., Tlais, S., Alkhatib, A., \& Hamdan, R. (2020). Effect of Four Grape Varieties on the Physicochemical and Sensory Properties of Unripe Grape Verjuice. Internatinal Journal of Food Science, 2020, https://doi.org/10.1155/2020/6457982.

Ergezer, H., Gökçe, R., \& Akcan, T. (2018). Koruk Sularının Bazı Kalite Karakteristikleri Üzerine Pastörizasyon ve Potasyum Sorbat İlavesinin Etkisi. Akademik G1da , 16(3), 287-292.

Eroğul, D., Oğuz, H., \& Şen, F. (2017). Ekşi, Mayhoş ve Tatlı Nar Genotiplerine Ait Meyvelerin Depolama Süresince
Bazı Fiziksel ve Kimyasal Özelliklerinin Belirlenmesi. Meyve Bilimi, 1, 34-39.

Faikoğlu, F. (2014). Adakarası, Papazkarası, Kalecikkarası Üzüm Çeşitleri Kullanılarak Üretilen Hardaliyelerin Kalitesinin ve Duyusal Özelliklerinin Araştırılması. Yüksek Lisans Tezi, Bursa Uludağ Üniversitesi, Fen Bilimleri Enstitüsü, Gıda Mühendisliği Anabilim Dalı, Bursa, 73s.

Fia, G., Bucalossi, G., Gori, C., Borghini, F., \& Zanoni, B. (2020). Recovery of Bioactive Compounds from Unripe Red Grapes (cv. Sangiovese) through a Green Extraction. Foods, 9(5), 566. https://doi.org/10.3390/foods9050566

Hayoğlu, I., Kola, O., Kaya, C., Özer, S., Türkoğlu, H. (2009). Chemical and Sensory Properties of Verjuice, A Traditional Turkish Non-Fermented Beverage From Kabarcik and Yediveren Grapes. Journal of Food Processing and Preservation, 33, 252-263.

Hidalgo, G. I., \& Almajano, M. P. (2017). Red Fruits: Extraction of Antioxidants, Phenolic Content, and Radical Scavenging Determination: A Review. Antioxidants, 6(1), 7. https://doi.org/10.3390/antiox6010007.

Gil, M. I., Tomás-Barberán, F. A., Hess-Pierce, B., Holcroft, D. M., \& Kader, A. A. (2000). Antioxidant Activity of Pomegranate Juice and Its Relationship with Phenolic Composition and Processing. Journal of Agricultural and Food Chemistry, 48, 4581-4589.

Hoca, G. (2019). Bursa İlinde Tüketime Sunulan Nar Ekşisi ve Nar Ekşili Soslarda Sorbik Asit ve Benzoik Asit Miktarlarının Belirlenmesi. Yüksek Lisans Tezi, Bursa Uludağ Üniversitesi, Fen Bilimleri Enstitüsü, Gıda Mühendisliği Anabilim Dalı, Bursa, 57s.

Jackman, R. L., Yada, R. Y., Tung, M. A., \& Speers, R. A. (1987). Anthocyanins and Food Colorants - A Review. Journal of Food Biochemistry, 11, 201-247.

Jin, Z. M., He, J. J., Bi, H. Q., Cui, X. Y., \& Duan, C. Q. (2009). Phenolic Compound Profiles in Berry Skins from Nine Red Wine Grape Cultivars in Northwest China. Molecules, 14(12), 4922-4935.

Kalaycığlu, Z., \& Bedia Erim, F. (2016). Total Phenolic Contents, Antioxidant Activities, and Bioactive Ingredients of Juices from Pomegranate Cultivars Worldwide. Food Chemistry, 221, 496-507.

Kamiloğlu, S., \& Çapanoğlu, E. (2014). In Vitro Gastrointestinal Digestion of Polyphenols from Different Molasses (Pekmez) and Leather (Pestil) Varieties. International Journal of Food Science and Technology, 49, 1027-1039.

Khanniri, E., Sohrabvandi, S., Mortazavian, A. M., Khorshidian, N., \& Malganji, S. (2018). Effect of Fermentation, Cold storage and Carbonation on the Antioxidant activity of Probiotic Grape Beverage. Current Nutrition \& Food Science, 14, 335. https://doi.org/10.2174/1573401313666170614100418

Kumaran, A., \& Karunakaran, R. J. (2006). Antioxidant and Free Radical Scavenging Activity of an Aqueous Extract of Coleus aromaticus. Food Chemistry, 97(1), 109-114.

Lee, J., Durst, R. W., \& Wrolstad, R. E. (2005). Determination of Total Monomeric Anthocyanin Pigment Content of Fruit Juices, Beverages, Natural Colorants, and Wines by the $\mathrm{pH}$ Differential Method: Collaborative Study. Journal of AOAC INTERNATIONAL, 88(5), 1269-1278.

Liu, Q., Tang, G. Y., Zhao, C. N., Feng, X. L., Xu, X. Y., Cao, S. Y., Meng, X., Li, S., Gan, R. Y., \& Li, H. B. (2018). 
Comparison of Antioxidant Activities of Different Grape Varieties. Molecules, 23(10), 2432. https://doi.org/10.3390/molecules23102432.

Mateus, N., Machado, J. M. \& Freitas, V. (2002). Development Changes of Anthocyanins in Vitis Vinifera Grapes Grown in the Douro Valley and Concentration in Respective Wines. Journal of the Science of Food and Agriculture, 82, 1689-1695.

Mena, P., Girones-Vilaplana, A., Marti, N., \& Garcia-Viguera, C. (2012). Pomegranate Varietal Wines: Phytochemical Composition and Quality Parameters. Food Chemistry, 133, 108-115.

Miller, N. J., \& Rice-Evans, C. (1997). Factors Influencing the Antioxidant Activity Determined By the ABTS •+ Radical Cation Assay. Free Radical Research, 26(6), 195-199.

Mousavi, Z. E., Mousavi, S. E., Razavi, S. H., Hadinejad, M., Emam-Djomeh, Z., \& Mirzapour, M. (2013). Effect of Fermentation of Pomegranate Juice by Lactobacillus plantarum and Lactobacillus acidophilus on the Antioxidant Activity and Metabolism of Sugars, Organic Acids and Phenolic Compounds. Food Biotechnology, 27(1), 1-13.

Navarro, S., Leon, M., Roca-Perez, L., Boluda, R., GarciaFerriz, L., Perez-Bermudez, P., \& Gavidia, I. (2008). Characterisation of Bobal and Crujidera Grape Cultivars, In Comparison with Tempranillo and Cabernet Sauvignon: Evolution of leaf macronutrients and berry composition during grape ripening. Food Chemistry, 108, 182-190.

Orak, H. H. (2009). Evaluation of Antioxidant Activity, Colour and Some Nutritional Characteristics of Pomegranate (Punica granatum L.) Juice and Its Sour Concentrate Processed By Conventional Evaporation. International Journal of Food Science and Nutrition, 60(1), 1-11.

Ordoudi, S. A., Mantzouridou, F., Daftsiou, E., Malo, C., Hatzidimitriou, E., Nenadis, N., \& Tsimidou, M. Z. (2014). Pomegranate Juice Functional Constituents After Alcoholic and Acetic Acid Fermentation. Journal of Functional Foods, 8, 161-168.

Otağ, M. R. (2015). Denizli Çal Yöresinde Yetişen Bazı Üzüm Çeşitlerinin Farklı Olgunlaşma Evreleri ve Kurutulması Sonrasında Bazı Özellikleri İle Resveratrol İçeriğinin Belirlenmesi. Doktora Tezi, Pamukkale Üniversitesi, Fen Bilimleri Enstitüsü, Gıda Mühendisliği Anabilim Dalı, Denizli, 148s.

Öncül, N., \& Karabıyıklı, Ş. (2015). Factors Affecting the Quality Attributes of Unripe Grape Functional Food Products. Journal of Food Biochemistry, 39, 689-695.

Özmert Ergin, S. (2020). Investigation of the Physicochemical, Nutritional Properties and Antioxidant Activities of Commercial and Traditional Pomegranate Molasses Samples. Food and Health, 6(3), 177-185.

Özmert Ergin, S. (2019). Nar Meyvesi (Punica granatum L.) ile Farklı Nar Ürünlerinin Antioksidan Özellikleri. Akademik G1da, 17(2), 243-251.

Rababah, T. M., Al-Mahasneh, M. A., Kilani, I., Yang, W., Almamad, M. N., Ereifej, K., \& Al-U'datt, M. (2013). Effect of Jam Processing and Storage on Total Phenolics, Antioxidant Activity, and Anthocyanins of Different Fruits. Journal of the Science Food and Agriculture, 91(6), 10961102.

Rein, M. (2005). Copigmentation Reactions and Color Stability of Berry Anthocyanins. $\mathrm{PhD}$ Thesis, University of Helsinki.
Sepulveda, E., Saenz, C., Pena, A., Robert, P, Bartolome B, \& Gomez-Cordoves C. (2010). Influence of the Genotype on the Anthocyanin Composition, Antioxidant Capacity and Color Of Chilean Pomegranate [Punica granatum L.] Juices. Chilean Journal of Agricultural Research, 70(1), 5057.

Shakir, B. K., \& Salih Rashid, R. (2019). Physiochemical and Phytochemical Profile of Unripe Black Grape Juice (Verjuice). Annals of Tropical Medicine and Public Health, 22, 48-61.

Tezcan F., Gültekin-Özgüven M., Diken T., Özçelik B., \& Erim F. B. (2009). Antioxidant Activity and Total Phenolic, Organic Acid and Sugar Content in Commercial Pomegranate Juices. Food Chemistry, 115, 873-877.

Türkmen Özen, İ. (2015). Siyah Üzüm Suyunda Antosiyanin Dağılımı ve İşleme ve Depolama Sırasında Değişimi. Doktora Tezi, Ankara Üniversitesi, Fen Bilimleri Enstitüsü, Gıda Mühendisliği Anabilim Dalı, Ankara, 116s.

Türkyılmaz, M. (2013). Anthocyanin and Organic Acid Profiles of Pomegranate (Punica granatum L.) Juices from Registered Varieties in Turkey. International Journal of Food Science \& Technology, 48, 2086-2095.

Tüzün, S., Baş, İ., Karakavuk, E., Karaca Sanyürek, N., \& Benzer, F. (2020). Çeşitli Pekmez Türlerinde Farklı Yöntemlerle Tespit Edilen Antioksidan Aktivitelerin Karşılaştırılması. Türk Tarım ve Doğa Bilimleri Dergisi, $7(2), 323-330$.

Vatansever, A. (2018). Nar ve Ürünlerinin Fizikokimyasal ve Biyokimyasal Özelliklerinin Belirlenmesi. Yüksek Lisans Tezi, Bursa Uludağ Üniversitesi, Fen Bilimleri Enstitüsü, Gıda Mühendisliği Anabilim Dalı, Bursa, 81s.

Wu, X., Beecher, G. R., Holden, J. M., Haytowitz, D. B., Gebhardt, S. E., Prior, R. L. (2006). Concentrations of Anthocyanins in Common Foods in The United States and Estimation of Normal Consumption. Journal of Agricultural and Food Chemistry, 54, 4069-4075.

Zhishen, J., Mengcheng, T., \& Jianming, W. (1999). The Determination of Flavonoid Contents in Mulberry and Their Scavenging Effects on Superoxide Radicals. Food Chemistry, 64, 555-559.

Zhuang, H., Du, J., \& Wang, Y. (2011). Antioxidant Capacity Changes of 3 Cultivar Chinese Pomegranate (Punica granatum L.) Juices and Corresponding Wines. Journal of Food Science, 76, 606-611. 